\title{
DNA Analysis of Ralstonia solanacearum and Related Bacteria Based on 282-bp PCR-Amplified Fragment
}

Joselito Villa, United Graduate School of Agricultural Science, Gifu University, Yanagido, Gifu 501-1183 Japan; Kenichi Tsuchiya, National Institute for Agro-Environmental Sciences, Kannondai 3-1-3, Tsukuba, Ibaraki 3058604, Japan; Mitsuo Horita, National Institute of Agrobiological Resources, Kannondai 2-1-2, Tsukuba 305-8602, Japan; Marina Natural, Department of Plant Pathology, University of the Philippines Los Baños, College, Laguna 4031, Philippines; Nenita Opina, Plant Pathology Laboratory, Institute of Plant Breeding, College, Laguna 4031, Philippines; and Mitsuro Hyakumachi, Laboratory of Plant Disease Science, Gifu University, 1-1Yanagido, Gifu 501-1183, Japan

\begin{abstract}
Villa, J., Tsuchiya, K., Horita, M., Natural, M., Opina, N., and Hyakumachi, M. 2003. DNA analysis of Ralstonia solanacearum and related bacteria based on 282-bp PCR-amplified fragment. Plant Dis. 87:1337-1343.

Strains of Ralstonia solanacearum, Pseudomonas syzygii, and the blood disease bacterium (BDB) from different countries were tested for polymerase chain reaction amplification of the 282-bp fragment using the primer pair 759 and 760 . These 282-bp fragments from 49 strains of $R$. solanacearum, six strains of $P$. syzygii, and two strains of BDB were sequenced. A phylogenetic tree was generated based on the sequence alignment. The $R$. solanacearum strains were divided into three groups. Group I was composed of strains belonging to biovars 3, 4, 5, and biovar N2 from Japan. Most of the strains from this group were of Asian origin except for two strains from Australia and Guyana (GMI 1000), the type strain. Group II was composed of strains belonging to biovars 1 and 2 and biovar N2 from Brazil. Group III was composed of strains belonging to biovar N2 from Japan and the Philippines. All strains of P. syzygii and BDB clustered in group III. Based on nucleotide differences of the 282-bp fragments, restriction enzyme NlaIII was capable of differentiating $R$. solanacearum strains into the three groups. Restriction analysis of 165 R. solanacearum isolates from the Philippines using NlaIII showed that all biovar 3 and 4 (group 1) strains had restriction fragments of 116 and $166 \mathrm{bp}$, strains belonging to biovars 1 and 2 (group 2) showed no restriction, and one strain belonging to biovar 2 (group 3) showed restriction fragments of 54 and 228 bp in size. Thus, NlaIII could be used for rapid differentiation of $R$. solanacearum strains. Additionally, other restriction enzymes, such as $M c r \mathrm{I}, B s i \mathrm{EI}$, and $M n l \mathrm{I}$ could be used to differentiate $R$. solanacearum strains from $P$. syzygii strains.
\end{abstract}

Additional keywords: bacterial wilt

Bacterial wilt caused by Ralstonia solanacearum (E. F. Smith) Yabuuchi et al. is one of the most important plant bacterial diseases in the Philippines and in the world. $R$. solanacearum attacks most genera within the family Solanaceae and some genera of over 50 other families of higher plants. It is very destructive in tomato, potato, eggplant, tobacco, banana, and ginger, where it causes serious reduction in yield and quality of products. In the tropics, where planting occurs year round, bacterial wilt damage to crops is omnipresent. In temperate regions, bacterial wilt, mainly in potato, is more important due to quarantine status than for damage caused.

Corresponding author: Kenichi Tsuchiya

E-mail: kentsuch@affrc.go.jp

Accepted for publication 7 June 2003.

Publication no. D-2003-0915-01R

(c) 2003 The American Phytopathological Society
$R$. solanacearum strains are classified mainly according to race and biovar. Recently, Fegan and Prior (6) proposed a hierarchical classification scheme. The strains are divided into four phylotypes by sequence analysis of the internal transcribed spacer (ITS) region. Phylotypes I and II are equivalent to divisions 1 and 2 defined by Cook et al. (4). Phylotype III contains strains from Africa and phylotype IV contains Indonesian strains (biovars 1, 2, and 2T), some strains found in Australia and Japan, and close relatives of $R$. solanacearum, Pseudomonas syzygii and the "blood disease bacteria" (BDB). Phylotypes are further subdivided to sequevars. Sequevars are defined from partial endoglucanase gene sequence. This new scheme will provide instant information about the geographic origin and pathogenicity of the strains.

Recently, sporadic outbreaks of brown rot of potato in Western Europe were reported. Importation of contaminated potato tubers was probably responsible for the introduction of the pathogen to different European countries. Bacterial wilt disease is known to spread among countries through infected and latently infected seed potato, ginger, banana corms, and Heliconia rhizomes $(11,14,19,24)$. Hence, detection and characterization of the bacteria is essential. It is conventionally done by immunofluorescence, isolation on culture medium, and tomato host test followed by biovar testing (16). However, identification can be quite laborious and take up to 4 weeks to complete. This problem can now be overcome by the use of molecular techniques that can rapidly detect and characterize microorganisms in a shorter time.

Several primers have been developed for detection of $R$. solanacearum strains using polymerase chain reaction assays. Among the primers that were developed by Opina et al. (20), the primer pair 759 and 760 consistently amplified a 282-bp fragment from all $R$. solanacearum strains, and from the DNA of closely related bacteria tested, namely $P$. syzygii (Sumatra disease of cloves) and the BDB affecting bananas. These primers have potential for rapid differentiation and identification of strains of $R$. solanacearum, P. syzygii, and BDB.

The objectives of this study were to (i) determine the phylogenetic relationships of $R$. solanacearum, $\mathrm{BDB}$, and $P$. syzygii based on the 282-bp sequences of the polymerase chain reaction (PCR)-amplified fragment obtained using primers 759 and 760 and (ii) characterize $R$. solanacearum strains based on the restriction fragment length polymorphism (RFLP) pattern of the 282-bp PCR-amplified fragment.

\section{MATERIALS AND METHODS}

Bacterial strains and growing conditions. $R$. solanacearum isolates used in this study represent the various strains infecting different hosts and their worldwide distribution (Table 1). Asian strains include 25 from the Philippines, 8 from Japan, 1 from China, and 11 from Indonesia. The rest of the world was represented by strains coming from the Americas, Europe, Australia, and Africa. The $R$. solanacearum strains were isolated from various hosts including banana (Musa spp.), potato (Solanum tube- 
rosum), tomato (Lycopersicum esculentum), Zingiber aromaticum, ginger ( $Z$. officinale Roscoe), mulberry (Morus alba L.), bird-of-paradise (Strelitzia reginae), eggplant (Solanum melongena), and bitter gourd (Momordica charantia). Philippine isolates of $R$. solanacearum used in this study were from the Institute of Plant Breeding Plant Pathology Laboratory and the Department of Plant Pathology of the

Table 1. List of Ralstonia solanacearum, Pseudomonas syzygii, and blood disease bacteria (BDB) strains used for phylogenetic analysis of the nucleotide sequences of 282-bp polymerase chain reaction fragments amplified using primers 759 and 760

\begin{tabular}{|c|c|c|c|c|c|c|}
\hline Strain & $\begin{array}{c}\text { Biovar } \\
\text { or genus }\end{array}$ & Race & Subgroup & Host & Origin & Source $^{a}$ \\
\hline T 237 & 3 & $\ldots$ & IA & Tomato & Philippines & $\mathrm{A}$ \\
\hline $\mathrm{T} 151$ & 3 & 1 & IA & Tomato & Philippines & A \\
\hline P33 & 4 & $\ldots$ & IA & Tomato & Philippines & $\mathrm{A}$ \\
\hline MAFF 301485 & $\mathrm{~N} 2$ & 1 & IA & Tomato & Japan & $\mathrm{E}$ \\
\hline MAFF 301560 & 3 & 1 & IA & Strelitzia reginae & Japan & $\mathrm{E}$ \\
\hline E 5 & 4 & $\ldots$ & IA & Eggplant & Philippines & $\mathrm{A}$ \\
\hline A 20 & 3 & $\ldots$ & IA & Bitter gourd & Philippines & A \\
\hline $2 \mathrm{M}$ & 3 & $\ldots$ & IA & Potato & Philippines & $\mathrm{B}$ \\
\hline R277 & 4 & 4 & IA & Ginger & Australia & $\mathrm{C}$ \\
\hline MAFF301860 & 3 & 1 & IA & Capsicum annuum & Japan & $\mathrm{E}$ \\
\hline MAFF301488 & $\mathrm{N} 2$ & 1 & IA & Tomato & Japan & $\mathrm{E}$ \\
\hline MAFF301522 & 3 & 1 & IA & Tomato & Japan & $\mathrm{E}$ \\
\hline Т 639 & 3 & $\ldots$ & IB & Tomato & Philippines & A \\
\hline Т 651 & 4 & $\ldots$ & $\mathrm{IC}$ & Tomato & Philippines & A \\
\hline $42 \mathrm{~T}$ & 4 & $\ldots$ & $\mathrm{IC}$ & Potato & Philippines & $\mathrm{B}$ \\
\hline R 292 & 5 & 5 & $\mathrm{IC}$ & Mulberry & China & $\mathrm{C}$ \\
\hline MAFF 301520 & 4 & 1 & $\mathrm{IC}$ & Eggplant & Japan & $\mathrm{E}$ \\
\hline MAFF 211266 & 4 & 1 & $\mathrm{IC}$ & Tomato & Japan & $\mathrm{E}$ \\
\hline $\mathrm{T} 870$ & 3 & $\ldots$ & $\mathrm{IC}$ & Ginger & Indonesia & $\mathrm{C}$ \\
\hline T625-98 & 4 & $\ldots$ & $\mathrm{IC}$ & Potato & Indonesia & $\mathrm{C}$ \\
\hline MAFF301556 & 4 & 1 & $\mathrm{IC}$ & Potato & Japan & $\mathrm{E}$ \\
\hline GMI 1000 & 3 & 1 & ID & Tomato & Guyana & $\mathrm{D}$ \\
\hline P3-332 (Moko) & 1 & 2 & IIA & Banana & Philippines & $\mathrm{B}$ \\
\hline Mod 5 (Moko) & 1 & 2 & IIA & Banana & Philippines & $\mathrm{B}$ \\
\hline Bsbr202-3a & 1 & 2 & IIA & Banana & Philippines & $\mathrm{B}$ \\
\hline 761a (Bugtok) & 1 & 2 & IIA & Banana & Philippines & $\mathrm{B}$ \\
\hline lb 1(Bugtok) & 1 & 2 & IIA & Banana & Philippines & $\mathrm{B}$ \\
\hline Mod 6 (Moko) & 1 & 2 & IIA & Banana & Philippines & $\mathrm{B}$ \\
\hline PD 1445 & 1 & 2 & IIA & Banana & Panama & $\mathrm{B}$ \\
\hline Bu5B (Bugtok) & 1 & 2 & IIA & Banana & Philippines & B \\
\hline B2 (Moko) & 1 & 2 & IIA & Banana & Philippines & $\mathrm{B}$ \\
\hline WP 320 & 2 & $\ldots$ & IIB & Potato & Philippines & $\mathrm{B}$ \\
\hline ACH 0158 & 2 & 3 & IIB & Potato & Australia & $\mathrm{D}$ \\
\hline PD 1939 & 2 & $\ldots$ & IIB & Potato & Israel & $\mathrm{C}$ \\
\hline PD 1260 & 2 & $\ldots$ & IIB & Potato & Reunion & $\mathrm{C}$ \\
\hline PD 441 & 2 & $\ldots$ & IIB & Potato & Sweden & $\mathrm{C}$ \\
\hline Т980 & 2 & $\ldots$ & IIB & Potato & Indonesia & $\mathrm{C}$ \\
\hline Т979 & 2 & $\ldots$ & IIB & Potato & Indonesia & $\mathrm{C}$ \\
\hline T697-1 & 2 & $\ldots$ & IIB & Potato & Indonesia & $\mathrm{C}$ \\
\hline T697-2 & 2 & $\ldots$ & IIB & Potato & Indonesia & $\mathrm{C}$ \\
\hline WP 305 & 2 & $\ldots$ & IIB & Potato & Philippines & $\mathrm{B}$ \\
\hline WP 306 & 2 & $\ldots$ & IIB & Potato & Philippines & $\mathrm{B}$ \\
\hline $10 \mathrm{~L}$ & 2 & $\ldots$ & IIB & Potato & Philippines & $\mathrm{B}$ \\
\hline WP 315 & 2 & $\ldots$ & IIB & Potato & Philippines & $\mathrm{B}$ \\
\hline R568 & $\mathrm{N} 2$ & $\ldots$ & IIC & Potato & Brazil & $\mathrm{C}$ \\
\hline PD 1938 & 1 & 1 & IID & Tomato & USA & $\mathrm{C}$ \\
\hline ATCC $11696^{\mathrm{T}}$ & 1 & 1 & IID & Tomato & USA & $\mathrm{C}$ \\
\hline MAFF 301559 & $\mathrm{~N} 2$ & 3 & IIIA & Potato & Japan & $\mathrm{E}$ \\
\hline MAFF 301558 & $\mathrm{~N} 2$ & 3 & IIIA & Potato & Japan & $\mathrm{E}$ \\
\hline WP 20 & 2 & $\ldots$ & IIIB & Potato & Philippines & A \\
\hline $28 \mathrm{MF}$ & 2 & $\ldots$ & IIIB & Potato & Philippines & $\mathrm{B}$ \\
\hline T520 & $\mathrm{BDB}$ & $\ldots$ & IIIC & Banana & Indonesia & $\mathrm{C}$ \\
\hline T633 & $\mathrm{BDB}$ & $\ldots$ & IIIC & Banana & Indonesia & $\mathrm{C}$ \\
\hline T544 & P. syzygii & $\ldots$ & IIID & Clove & Indonesia & $\mathrm{C}$ \\
\hline T329 & P. syzygii & $\ldots$ & IIID & Clove & Indonesia & $\mathrm{C}$ \\
\hline S444E & P. syzygii & $\ldots$ & IIID & Clove & Indonesia & $\mathrm{C}$ \\
\hline T555 & P. syzygii & $\ldots$ & IIIE & Clove & Indonesia & $\mathrm{C}$ \\
\hline T545 & P. syzygii & $\ldots$ & IIIE & Clove & Indonesia & $\mathrm{C}$ \\
\hline T547 & P. syzygii & $\ldots$ & IIIE & Clove & Indonesia & $\mathrm{C}$ \\
\hline
\end{tabular}

a Strain or sequence was obtained from : A = N. L. Opina of the Plant Pathology Laboratory, Institute of Plant Breeding, University of the Philippines, Los Baños, Philippines; B = Marina P. Natural of the Department of Plant Pathology, University of the Philippines, Los Baños, Philippines; C $=\mathrm{K}$. Tsuchiya of the Microbial Genetics and Physiology Unit, National Institute for AgroEnvironmental Sciences, Japan; D = National Center for Biotechnology Information; and E = Ministry of Agriculture, Forestry and Fisheries, Genebank Japan.

University of the Philippines, Los Baños. Strains of $R$. solanacearum, $P$. syzygii, $P$. aeruginosa, $R$. picketti, and the $\mathrm{BDB}$ were from the Ministry of Agriculture, Forestry and Fisheries (MAFF) Genebank Culture Collection, and obtained from the Microbial Genetics and Physiology Unit, National Institute for Agro-Environmental Sciences, Japan.

$R$. solanacearum strains were grown on tetrazolium chloride agar (TZCA) medium (17) at $30^{\circ} \mathrm{C}$ for 2 to 3 days. A loopful of bacterial growth was suspended in sterile distilled water in $1.5-\mathrm{ml}$ tubes. The bacterial cells were heated over a $100^{\circ} \mathrm{C}$ water bath for $10 \mathrm{~min}$ and then were used for PCR. Alternatively, genomic DNA was used for some strains. The DNA was prepared using the method of Chen and Kuo (2).

PCR amplification and DNA purification. A pair of primers specific to $R$. solanacearum was used (20). This primer pair, 759 (5'-GTCGCCGTCAACTCACT TTCC- $\left.3^{\prime}\right)$ and 760 (5'-GTCGCCGTC AGCAATGCGGAATCG-3'), was expected to amplify a 281-bp fragment.

PCR was done using the optimized reactions for primers 759 and $760(1 \times$ buffer, $1.5 \mathrm{mM} \mathrm{MgCl}_{2}, 0.05 \mathrm{mM}$ each dNTP, primers at $0.5 \mathrm{pmol}^{-1} \mathrm{l}^{-1}$, and Takara Taq at $0.01 \mathrm{U} \mathrm{\mu l}^{-1}$ ) made by Opina et al. (20). About $2 \mu \mathrm{l}$ of boiled cells or 1 to $10 \mathrm{ng}$ of DNA was used for each PCR reaction (20 to $25 \mu \mathrm{l}$ ). A Perkin-Elmer (Norwalk, CT) automated thermocycler was used for the PCR amplifications. The thermal cycle consisted of initial denaturation at $94^{\circ} \mathrm{C}$ for $3 \mathrm{~min}$, annealing at $53^{\circ} \mathrm{C}$ for $1 \mathrm{~min}$, and extension at $72^{\circ} \mathrm{C}$ for $1.5 \mathrm{~min}$, followed by 30 cycles of $94^{\circ} \mathrm{C}$ for $15 \mathrm{~s}, 60^{\circ} \mathrm{C}$ for $15 \mathrm{~s}$, $72^{\circ} \mathrm{C}$ for $15 \mathrm{~s}$, and a final extension of $72^{\circ} \mathrm{C}$ for $5 \mathrm{~min}$.

The PCR products were resolved in $1.5 \%$ agarose gel and stained in ethidium bromide solution. Amplified 282-bp DNA fragments were purified from the agarose gel using a Geneclean Spin kit (BIO 101 Inc., La Jolla, CA) or QIA quick gel extraction kit (Qiagen Inc., Hilden, Germany) prior to sequencing according to the manufacturer's instructions.

DNA sequencing and analysis. Sequencing was done using Big Dye Terminator V3.0 (Applied Biosystems, Tokyo) according to the manufacturer's instructions. Gene Amp System 9600 (PerkinElmer Applied Biosystems, Tokyo) was used for the PCR sequencing reaction and sequences were determined using an Applied Biosystems prism 3100 DNA sequencer (Perkin Elmer Applied Biosystems).

The 282-bp fragment sequences of the 59 strains of $R$. solanacearum, $P$. syzygii, and BDB were aligned using the Clustal W software package (31). A phylogenetic tree was constructed using Neighbor Joining Plot. The strength of the tree branches was tested by 1,000 bootstrap trials. The unique enzyme restriction sites were determined 
using Vector NTI software (Informax Inc., Bethesda, MD).

RFLP. The $165 R$. solanacearum strains collected from 99 sites in the Philippines and isolated from different crops (potato, eggplant, pepper, tomato, and bitter gourd) were characterized using NlaIII enzyme (New England Biolabs Inc., Beverly, MA). Strains first were tested for amplification of 282-bp fragments in PCR using primers 759 and 760 . The PCR-amplified fragments were digested as specified in the manufacturer's instructions. Restriction products were run for $30 \mathrm{~min}$ in $4.5 \% \mathrm{Nu}$ Sieve GTG agarose gel using $1 \times$ Trisacetate-EDTA buffer.

\section{RESULTS}

Sequence analysis. A worldwide collection of 49 strains of $R$. solanacearum, 2 strains of BDB, and 6 strains of $P$. syzygii was used for sequencing of fragments amplified by primers 759 and 760 . Based on the results, the total number of nucleotides amplified was 282. Thus, in this study, we referred to the amplified fragment as a 282- instead of 281-bp fragment, as previously reported by Opina et al. (20). PCR amplification of the 282-bp fragment from different strains of $R$. solanacearum is shown in Figure 1. The 282-bp fragment consistently was amplified from all $R$. solanacearum strains but not from $P$. aeruginosa or $R$. picketti isolates.

The sequences of primer 759 (21 bp) and primer 760 (24 bp) were excluded from the sequence analysis of the 282-bp band. Hence, only the remaining $237 \mathrm{nu}-$ cleotide (nt) positions were considered in the comparison. Nucleotide sequences from ACHO158 (accession no. AF254622) and type strain GMI1000 (accession no. AL646072), obtained from the National Center for Biotechnology Information data bank, that were homologous to the 282-bp fragment were included in the analysis. The phylogenetic tree produced after comparing the $237 \mathrm{nt}$ positions divided the $R$. solanacearum, $\mathrm{BDB}$, and $P$. syzygii strains into three major groups (Fig. 2). Strains belonging to previously defined groups (e.g., biovars or races) clustered into distinct groups. Furthermore, the three groups were divided into a total of 13 subgroups based on the results of multiple sequence alignment. The high bootstrap value signifies that the groups and some subgroups were well supported and the analysis was robust. Group I was composed mainly of race 1 strain from Australia, Japan, the Philippines, and Guyana. Group II consisted of races 1, 2, and 3 strains. Group III contained biovars N2 (Japan) and 2 (the Philippines), and the strains of BDB and $P$. syzygii.

The sequencing results revealed abundant polymorphisms within the 237 nucleotide sequences of the PCR-amplified 282-bp fragment of $R$. solanacearum, BDB, and P. syzygii. All in all, there were

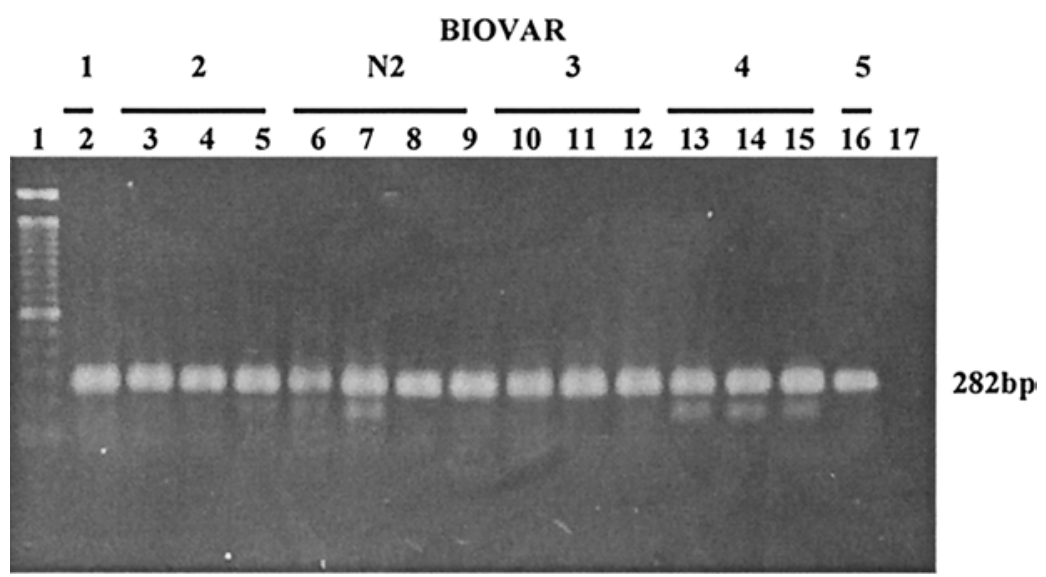

Fig. 1. Polymerase chain reaction amplifications of 282-bp fragments from different strains of Ralstonia solanacearum belonging to different biovars and isolated from different parts of the world. Lane 1, 100-bp marker; lane 2, ATCC11696 (biovar 1); lane 3, PD441 (biovar 2); lane 4, PD1260 (biovar 2); lane 5, PD1939 (biovar 2); lane 6, MAFF 301485 (biovar N2); lane 7, MAFF 301488 (biovar N2); lane 8, MAFF 301588 (biovar N2); lane 9, MAFF 301559 (biovar N2); lane 10, MAFF 301522 (biovar 3); lane 11, MAFF 301560 (biovar 3); lane 12, MAFF 301860 (biovar 3); lane 13, MAFF 211266 (biovar 4); lane 14, MAFF 301520 (biovar 4); lane 15, MAFF 301556 (biovar 4); lane 16, R292 (biovar 5); and lane 17, negative control.

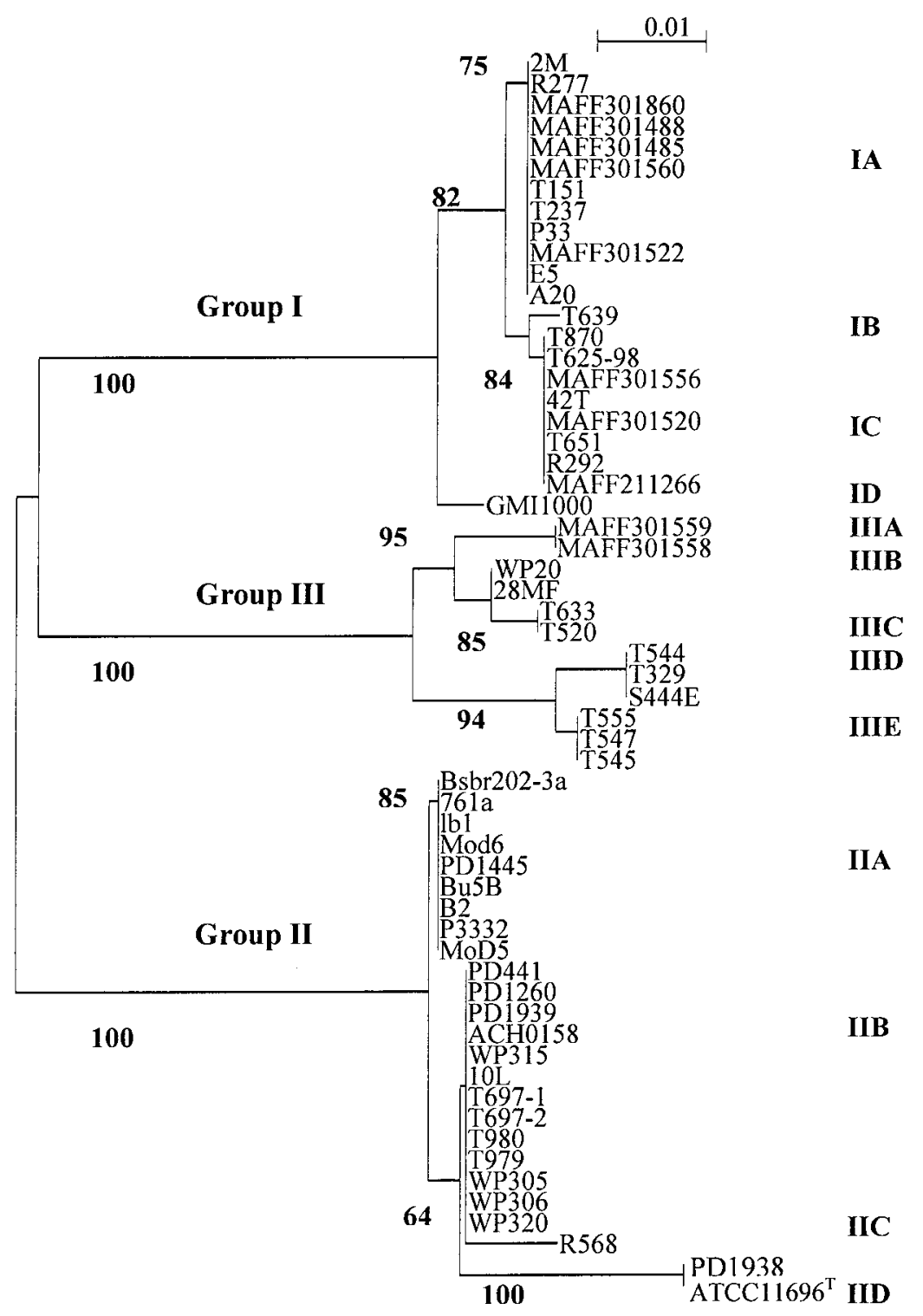

Fig. 2. Phylogenetic tree generated from the comparison of 237 nucleotides of Ralstonia solanacearum, blood disease bacteria, and Pseudomonas syzygii isolates amplified by polymerase chain reaction using primers 759 and 760 . The numbers at the points are the percentage of bootstrap replicates in which the groups and subgroups occurred. 
about $44 \mathrm{nt}$ position variations in the 59 strains analyzed. The nucleotide positions where the subgroups differed are shown in Table 2. The overall level of nucleotide similarity of the 59 strains ranged from 81.4 to $100 \%$. The nucleotide similarity among the $R$. solanacearum strains was about $83.1 \%$ (197 nt). The isolates of $P$. syzygii had about $98.7 \%$ nucleotide similarity with $R$. solanacearum (234 nt). The nucleotide sequences of strains of BDB were very similar to the $R$. solanacearum strains (subgroup IIIB), having only $1 \mathrm{nt}$ difference between them. On nucleotide position 40436, there is a thymine instead of cytosine in BDB strains. On the other hand, the similarity of the sequences between the strains of $\mathrm{BDB}$ and $P$. syzygii was $97.9 \%$.

Groups I and III have $87.3 \%$ similarity (207 out of $237 \mathrm{nt}$ ). A higher similarity between these two groups $(89.9 \%$ or 213 nt) was obtained when the BDB and $P$. syzygii strains were excluded from the comparisons. Furthermore, the similarity between groups I and II was $87.3 \%$ (207 nt) and the similarity between groups II and III was lowest at $86.1 \%$ (204 nt). However, if the BDB and the P. syzygii strains were removed from group III, the similarity rose to $87.8 \%$ (208 nt).

The groups or subgroups were characterized by the similarity and uniqueness in nucleotide positions. The highest level of nucleotide similarity between strains of the same group was seen in group I, wherein the nucleotide similarity ranged from 98.3 to $100 \%$. The 22 strains belonging to group 1 differed only in 4 nt positions. In group II, the similarity of the 25 member strains ranged from 96.6 to $100 \%$, having $8 \mathrm{nt}$ differences. Strains belonging to group III had the lowest similarity among the three groups at approximately 95.8 to $100 \%$. This was due to the sequence of BDB and $P$. syzygii strains that contributed seven different nucleotide positions. The similarity between the $R$. solanacearum strains in group III (subgroups IIIA and IIIB) is $98.7 \%$.

Restriction sites. Analysis of the nucleotide sequences of $R$. solanacearum, $P$. syzygii, and BDB revealed several restriction sites. Nine restriction sites that were unique in particular groups and subgroups can be utilized for differentiating the strains of $R$. solanacearum, $P$. syzygii, and BDB (Table 3). Most of these unique restriction sites also pertain to a particular biovar or race classification of $R$. solanacearum. BsrBI site was found only in banana strain (subgroup IIA). Csp61 and $R s a$ I sites were confined to tomato strains from America (subgroup II D).

Among the restriction enzymes, NlaIII could best differentiate the strains, based on three RFLP patterns, according to the three groups of the phylogenetic tree that was generated from the nucleotide se-

Table 2. Nucleotide position differences within the 282-bp polymerase chain reaction-amplified DNA among 13 subgroup classifications of Ralstonia solanacearum, blood disease bacteria, and Pseudomonas syzygii isolates

\begin{tabular}{|c|c|c|c|c|c|c|c|c|c|c|c|c|c|}
\hline \multirow[b]{2}{*}{ Nucleotide position ${ }^{a}$} & \multicolumn{13}{|c|}{ Subgroup } \\
\hline & IA & IB & IC & ID & IIA & IIB & IIC & IID & IIIA & IIIB & IIIC & IIID & IIIE \\
\hline 40399 & $\mathrm{C}$ & $\mathrm{C}$ & $\mathrm{C}$ & $\mathrm{C}$ & $\mathrm{C}$ & $\mathrm{C}$ & $\mathrm{C}$ & $\mathrm{C}$ & $\mathrm{C}$ & $\mathrm{C}$ & $\mathrm{C}$ & $\mathrm{T}$ & $\mathrm{T}$ \\
\hline 40418 & A & A & A & A & A & A & G & A & A & A & A & A & A \\
\hline 40423 & A & $\mathrm{A}$ & A & A & $\mathrm{G}$ & $\mathrm{G}$ & $\mathrm{G}$ & $\mathrm{G}$ & $\mathrm{G}$ & $\mathrm{G}$ & G & G & $\mathrm{G}$ \\
\hline 40427 & A & A & A & A & A & A & A & A & $\mathrm{G}$ & $\mathrm{G}$ & $\mathrm{G}$ & $\mathrm{G}$ & $\mathrm{G}$ \\
\hline 40428 & $\mathrm{G}$ & $\mathrm{G}$ & $\mathrm{G}$ & $\mathrm{G}$ & G & G & G & G & A & A & A & A & A \\
\hline 40430 & $\mathrm{~T}$ & $\mathrm{~T}$ & $\mathrm{~T}$ & $\mathrm{~T}$ & $\mathrm{~T}$ & $\mathrm{~T}$ & $\mathrm{C}$ & $\mathrm{T}$ & $\mathrm{T}$ & $\mathrm{T}$ & $\mathrm{T}$ & $\mathrm{T}$ & $\mathrm{T}$ \\
\hline 40436 & $\mathrm{C}$ & $\mathrm{C}$ & $\mathrm{C}$ & $\mathrm{C}$ & $\mathrm{C}$ & $\mathrm{C}$ & $\mathrm{C}$ & $\mathrm{C}$ & $\mathrm{C}$ & $\mathrm{C}$ & $\mathrm{T}$ & $\mathrm{C}$ & $\mathrm{C}$ \\
\hline 40438 & $\mathrm{C}$ & $\mathrm{C}$ & $\mathrm{C}$ & $\mathrm{C}$ & $\mathrm{C}$ & $\mathrm{C}$ & $\mathrm{C}$ & $\mathrm{C}$ & $\mathrm{G}$ & $\mathrm{C}$ & $\mathrm{C}$ & $\mathrm{C}$ & $\mathrm{C}$ \\
\hline 40439 & $\mathrm{G}$ & $\mathrm{G}$ & $\mathrm{G}$ & $\mathrm{G}$ & $\mathrm{G}$ & G & G & $\mathrm{G}$ & $\mathrm{T}$ & $\mathrm{T}$ & $\mathrm{T}$ & $\mathrm{T}$ & $\mathrm{T}$ \\
\hline 40462 & $\mathrm{~T}$ & $\mathrm{~T}$ & $\mathrm{~T}$ & $\mathrm{~T}$ & $\mathrm{G}$ & $\mathrm{G}$ & $\mathrm{G}$ & $\mathrm{G}$ & $\mathrm{T}$ & $\mathrm{T}$ & $\mathrm{T}$ & $\mathrm{T}$ & $\mathrm{T}$ \\
\hline 40472 & A & A & A & A & $\mathrm{G}$ & G & G & $\mathrm{G}$ & A & A & A & A & A \\
\hline 40497 & $\mathrm{C}$ & $\mathrm{C}$ & $\mathrm{C}$ & $\mathrm{C}$ & $\mathrm{T}$ & $\mathrm{T}$ & $\mathrm{T}$ & $\mathrm{T}$ & $\mathrm{C}$ & $\mathrm{C}$ & $\mathrm{C}$ & $\mathrm{C}$ & $\mathrm{C}$ \\
\hline 40499 & $\mathrm{C}$ & $\mathrm{C}$ & $\mathrm{C}$ & $\mathrm{C}$ & $\mathrm{T}$ & $\mathrm{T}$ & $\mathrm{T}$ & $\mathrm{T}$ & $\mathrm{T}$ & $\mathrm{T}$ & $\mathrm{T}$ & $\mathrm{T}$ & $\mathrm{T}$ \\
\hline 40501 & $\mathrm{G}$ & $\mathrm{G}$ & $\mathrm{G}$ & $\mathrm{G}$ & $\mathrm{C}$ & $\mathrm{C}$ & $\mathrm{C}$ & $\mathrm{C}$ & G & G & G & G & $\mathrm{G}$ \\
\hline 40534 & A & A & A & A & A & A & A & A & A & A & A & $\mathrm{T}$ & $\mathrm{T}$ \\
\hline 40536 & $\mathrm{C}$ & $\mathrm{C}$ & $\mathrm{C}$ & $\mathrm{C}$ & A & A & A & A & A & A & A & A & A \\
\hline 40542 & $\mathrm{G}$ & $\mathrm{G}$ & $\mathrm{G}$ & $\mathrm{G}$ & A & A & A & A & A & A & A & A & A \\
\hline 40543 & $\mathrm{~T}$ & $\mathrm{~T}$ & $\mathrm{~T}$ & $\mathrm{~T}$ & $\mathrm{G}$ & G & G & G & G & G & $\mathrm{G}$ & G & $\mathrm{G}$ \\
\hline 40545 & $\mathrm{G}$ & $\mathrm{G}$ & $\mathrm{G}$ & $\mathrm{G}$ & $\mathrm{G}$ & $\mathrm{G}$ & $\mathrm{G}$ & A & $\mathrm{G}$ & $\mathrm{G}$ & $\mathrm{G}$ & $\mathrm{G}$ & $\mathrm{G}$ \\
\hline 40547 & $\mathrm{G}$ & $\mathrm{G}$ & $\mathrm{G}$ & $\mathrm{G}$ & A & A & A & A & $\mathrm{G}$ & $\mathrm{G}$ & $\mathrm{G}$ & $\mathrm{G}$ & $\mathrm{G}$ \\
\hline 40550 & A & A & A & A & G & G & G & G & G & $\mathrm{G}$ & G & G & $\mathrm{G}$ \\
\hline 40557 & $\mathrm{G}$ & $\mathrm{G}$ & $\mathrm{G}$ & $\mathrm{G}$ & A & A & A & A & $\mathrm{T}$ & $\mathrm{T}$ & $\mathrm{T}$ & $\mathrm{T}$ & $\mathrm{T}$ \\
\hline 40558 & $\mathrm{C}$ & $\mathrm{C}$ & $\mathrm{C}$ & $\mathrm{C}$ & $\mathrm{T}$ & $\mathrm{T}$ & $\mathrm{T}$ & $\mathrm{T}$ & $\mathrm{T}$ & $\mathrm{T}$ & $\mathrm{T}$ & $\mathrm{T}$ & $\mathrm{T}$ \\
\hline 40560 & $\mathrm{C}$ & $\mathrm{C}$ & $\mathrm{C}$ & $\mathrm{C}$ & $\mathrm{T}$ & $\mathrm{T}$ & $\mathrm{T}$ & $\mathrm{T}$ & $\mathrm{T}$ & $\mathrm{T}$ & $\mathrm{T}$ & $\mathrm{T}$ & $\mathrm{T}$ \\
\hline 40571 & $\mathrm{G}$ & $\mathrm{G}$ & $\mathrm{G}$ & $\mathrm{G}$ & $\mathrm{G}$ & $\mathrm{G}$ & $\mathrm{G}$ & G & A & A & A & A & A \\
\hline 40572 & A & A & A & A & A & A & A & $\mathrm{C}$ & A & A & A & A & A \\
\hline 40573 & $\mathrm{~T}$ & $\mathrm{~T}$ & $\mathrm{~T}$ & $\mathrm{~T}$ & $\mathrm{G}$ & $\mathrm{G}$ & $\mathrm{G}$ & $\mathrm{G}$ & $\mathrm{T}$ & $\mathrm{T}$ & $\mathrm{T}$ & $\mathrm{T}$ & $\mathrm{T}$ \\
\hline 40576 & $\mathrm{C}$ & A & A & $\mathrm{C}$ & $\mathrm{C}$ & $\mathrm{C}$ & $\mathrm{C}$ & $\mathrm{C}$ & $\mathrm{C}$ & $\mathrm{C}$ & $\mathrm{C}$ & $\mathrm{C}$ & $\mathrm{C}$ \\
\hline 40579 & A & $\mathrm{A}$ & A & A & A & A & A & A & $\mathrm{G}$ & A & A & A & A \\
\hline 40581 & A & A & A & A & $\mathrm{G}$ & $\mathrm{G}$ & G & G & A & A & A & A & A \\
\hline 40588 & $\mathrm{G}$ & $\mathrm{G}$ & $\mathrm{G}$ & $\mathrm{G}$ & $\mathrm{G}$ & $\mathrm{G}$ & $\mathrm{G}$ & A & $\mathrm{G}$ & $\mathrm{G}$ & $\mathrm{G}$ & A & A \\
\hline 40592 & $\mathrm{G}$ & $\mathrm{G}$ & $\mathrm{G}$ & $\mathrm{G}$ & $\mathrm{G}$ & $\mathrm{G}$ & $\mathrm{G}$ & A & $\mathrm{G}$ & $\mathrm{G}$ & $\mathrm{G}$ & $\mathrm{G}$ & $\mathrm{G}$ \\
\hline 40595 & $\mathrm{C}$ & $\mathrm{C}$ & $\mathrm{C}$ & $\mathrm{C}$ & $\mathrm{C}$ & $\mathrm{C}$ & $\mathrm{C}$ & C & $\mathrm{T}$ & $\mathrm{T}$ & $\mathrm{T}$ & $\mathrm{C}$ & $\mathrm{C}$ \\
\hline 40597 & $\mathrm{G}$ & $\mathrm{G}$ & $\mathrm{G}$ & $\mathrm{G}$ & $\mathrm{G}$ & $\mathrm{G}$ & $\mathrm{G}$ & A & $\mathrm{G}$ & $\mathrm{G}$ & $\mathrm{G}$ & $\mathrm{G}$ & $\mathrm{G}$ \\
\hline 40602 & A & A & $\mathrm{G}$ & $\mathrm{G}$ & $\mathrm{G}$ & $\mathrm{G}$ & $\mathrm{G}$ & G & A & A & A & A & A \\
\hline 40603 & $\mathrm{~T}$ & $\mathrm{~T}$ & $\mathrm{~T}$ & $\mathrm{~T}$ & A & A & A & A & $\mathrm{T}$ & $\mathrm{T}$ & $\mathrm{T}$ & $\mathrm{T}$ & $\mathrm{T}$ \\
\hline 40604 & $\mathrm{G}$ & $\mathrm{G}$ & $\mathrm{G}$ & $\mathrm{G}$ & $\mathrm{G}$ & $\mathrm{C}$ & $\mathrm{C}$ & $\mathrm{C}$ & G & $\mathrm{T}$ & $\mathrm{T}$ & $\mathrm{T}$ & $\mathrm{T}$ \\
\hline 40609 & $\mathrm{~T}$ & $\mathrm{~T}$ & $\mathrm{~T}$ & $\mathrm{C}$ & $\mathrm{T}$ & $\mathrm{T}$ & $\mathrm{T}$ & $\mathrm{T}$ & $\mathrm{T}$ & $\mathrm{T}$ & $\mathrm{T}$ & $\mathrm{T}$ & $\mathrm{T}$ \\
\hline 40611 & $\mathrm{G}$ & $\mathrm{G}$ & $\mathrm{G}$ & $\mathrm{G}$ & $\mathrm{G}$ & G & G & $\mathrm{G}$ & A & A & A & A & A \\
\hline 40612 & $\mathrm{C}$ & $\mathrm{C}$ & $\mathrm{C}$ & $\mathrm{C}$ & $\mathrm{C}$ & $\mathrm{C}$ & $\mathrm{C}$ & $\mathrm{C}$ & $\mathrm{T}$ & $\mathrm{T}$ & $\mathrm{T}$ & $\mathrm{T}$ & $\mathrm{T}$ \\
\hline 40613 & $\mathrm{G}$ & $\mathrm{G}$ & $\mathrm{G}$ & $\mathrm{G}$ & $\mathrm{G}$ & $\mathrm{G}$ & $\mathrm{G}$ & $\mathrm{G}$ & $\mathrm{G}$ & $\mathrm{G}$ & $\mathrm{G}$ & $\mathrm{C}$ & $\mathrm{G}$ \\
\hline 40617 & $\mathrm{G}$ & $\mathrm{G}$ & $\mathrm{G}$ & $\mathrm{G}$ & G & G & G & G & A & A & A & A & A \\
\hline 40620 & $\mathrm{G}$ & $\mathrm{G}$ & $\mathrm{G}$ & A & A & A & A & A & A & A & A & A & A \\
\hline 40621 & $\mathrm{C}$ & $\mathrm{C}$ & $\mathrm{C}$ & $\mathrm{C}$ & $\mathrm{T}$ & $\mathrm{T}$ & $\mathrm{T}$ & $\mathrm{T}$ & $\mathrm{C}$ & $\mathrm{C}$ & $\mathrm{C}$ & $\mathrm{T}$ & $\mathrm{C}$ \\
\hline
\end{tabular}

a Numbering of the nucleotide position was based on numbering in the complete genome of $R$. solanacearum GMI 1000 strain (27). 
quence of the 282-bp fragment. This enzyme instantly sorted the Asian (biovars 3, 4, and 5), American (biovars 1 and 2), and $\mathrm{N} 2$ and BDB isolates.

The ability of NlaIII for differentiating the strains of $R$. solanacearum into three groups, based on the fingerprint types, were tested on Philippine strains. About 165 strains were collected from more than 99 sites (Table 4). The results separated the strains according to three distinct groups. Three fingerprint types corresponding to the biovar or race classifications were observed: (i) fragment size of 166 and $116 \mathrm{bp}$ for all 147 strains belonging to biovar 3 and 4, (ii) no restriction for all 10 strains belonging to biovar 1 (banana and tomato) and 7 strains from biovar 2 (potato), and (iii) fragment size of 228 and $54 \mathrm{bp}$ for 1 strain of biovar 2 (potato) isolated in the southern Philippines (Fig. 3).

\section{DISCUSSION}

This study made use of the 282-bp DNA fragment that can be amplified through PCR using the primer pair 759 and 760 , described by Opina et al. (20). Previous reports showed that this 282-bp band could be amplified from $R$. solanacearum strains from Australia, the Philippines, Taiwan, Japan, and the Americas $(15,20)$. This 282bp band is part of the putative $\operatorname{lp} x C$ gene, the gene for UDP-3- $O$-acyl $N$-acetylglucosamine deacetylase in $R$. solanacearum (27). This gene is located on the 3.7$\mathrm{Mb}$ chromosome of the bipartite genome structure of $R$. solanacearum GMI 1000 strain. The 237-bp sequence that remained after disregarding the primer sequence in this 282-bp band has a $63 \% \mathrm{G}+\mathrm{C}$ content, close to the $67 \% \mathrm{G}+\mathrm{C}$ content of the whole genome (8). Additionally, the 282-bp fragment also was amplified from two species of bacteria that are closely related to $R$. solanacearum; namely, $P$. syzygii, the causal agent of Sumatra disease of clove, and the banana BDB. Contrastingly, the fragment was not amplified from strains of $P$. aeruginosa and $R$. picketti, which were relatively less closely related to $R$. solanacearum. Thus, this 282-bp PCR fragment was observed to be ubiquitous and reflective of the whole genome of $R$. solanacearum and even its very close relatives, and could be amplified easily by PCR and characterized by RFLP, making it ideal for phylogenetic analysis. Roncal et al. were able to differentiate strains from Asia or Australia and the Americas using restriction enzymes HaeIII and MspI on 282 bp (26).
The genomic diversity of $R$. solanacearum and its close relatives was apparent on sequence analysis of the 237-bp DNA sequence. The strains were divided into three major groups. Groups I, II, and III corroborate the divisions $1,2 \mathrm{a}$, and $2 \mathrm{~b}$ observed in studies made using various methods $(4,12,13,18,21,22,28,29)$. In addition, groups I, II, and III agreed with phylotypes I, II, and IV, respectively, proposed by Fegan and Prior (6). A phylotype is a monophyletic cluster of strains made by phylogenetic analysis of sequence data from the ITS region, $h r p B$ gene, and endoglucanase gene. Unfortunately, strains from Africa were not represented in this study, which might have formed another group that corresponds to phylotype III of the new proposed scheme (6). Moreover,

Table 4. Summary list of Philippine strains used for polymerase chain reaction amplification of 282bp fragments and the corresponding restriction results using NlaIII $^{\mathrm{a}}$

\begin{tabular}{|c|c|c|c|c|c|}
\hline Host & $\begin{array}{c}\text { Number of } \\
\text { collection sites }\end{array}$ & Biovar & $\begin{array}{c}\text { Number } \\
\text { of strains }\end{array}$ & $\begin{array}{l}\text { RFLP fragment } \\
\text { size (bp) }\end{array}$ & Source $^{b}$ \\
\hline \multirow[t]{4}{*}{ Potato } & 37 & 2 & 7 & No restriction & B \\
\hline & & 2 & 1 & 54,228 & A \\
\hline & & 3 & 57 & 116,166 & A,B \\
\hline & & 4 & 1 & 116,166 & A \\
\hline \multirow[t]{2}{*}{ Eggplant } & 15 & 3 & 8 & 116,166 & A \\
\hline & & 4 & 17 & 116,166 & A \\
\hline \multirow[t]{2}{*}{ Pepper } & 11 & 3 & 9 & 116,166 & A \\
\hline & & 4 & 3 & 116,166 & A \\
\hline \multirow[t]{2}{*}{ Tomato } & 31 & 3 & 41 & 116,166 & A \\
\hline & & 4 & 7 & 116,166 & A \\
\hline Bitter gourd & 5 & 3 & 4 & 116,166 & A \\
\hline \multirow[t]{2}{*}{ Banana } & ND & 1 (Moko) & 6 & No restriction & B \\
\hline & & 1 (Bugtok) & 4 & No restriction & B \\
\hline
\end{tabular}

${ }^{a}$ RFLP $=$ restriction fragment length polymorphism and ND = no data.

b Strains were from: A = N. Opina, Plant Pathology Laboratory, Institute of Plant Breeding, UPLB, Los Baños, Philippines; and B = M. Natural, Department of Plant Pathology; UPLB, Los Baños, Philippines.

Table 3. Restriction enzymes that differentiated the Ralstonia solanacearum, blood disease bacterium (BDB), and Pseudomonas syzygii strains belonging to different biovars and races based on restriction fragment length polymorphism patterns of 282-bp fragments

\begin{tabular}{|c|c|c|c|c|}
\hline Restriction enzyme & $\begin{array}{l}\text { Approximate size of } \\
\text { restriction fragments (bp) }\end{array}$ & Group or subgroup & Biovar or genus & Race \\
\hline \multirow[t]{3}{*}{ NlaIII } & 116,166 & I & $3,4,5, \mathrm{~N} 2$ & 1 \\
\hline & No restriction & II & $1,2, \mathrm{~N} 2$ & $1,2,3$ \\
\hline & 54,228 & III & $\mathrm{N} 2, P$. syzygii, $\mathrm{BDB}$ & $\ldots$ \\
\hline \multirow[t]{5}{*}{$H g a \mathrm{I}$} & $55,66,161$ & IA, IB, IC & $3,4,5, \mathrm{~N} 2$ & 1 \\
\hline & $27,28,66,161$ & ID & 3 & 1 \\
\hline & 55,227 & II & $1,2, \mathrm{~N} 2$ & 2,3 \\
\hline & $24,94,161$ & IIIA, IIIB, IIIC, IIIE & $\mathrm{N} 2$, BDB, P. syzygii & $\ldots$ \\
\hline & 121,161 & IIID & P. syzygii & $\ldots$ \\
\hline DpnII, Sau3AI & 46,236 & IIID & P. syzygii & $\ldots$ \\
\hline NdeII MboI, BsbrBI & 51,231 & IIA & 1 & 2 \\
\hline \multirow{4}{*}{$M s p \mathrm{I}, H p h \mathrm{II}$} & $80,87,115$ & IIA & 1 & 2 \\
\hline & $29,51,87,115$ & IIB, IID & 1,2 & 1,3 \\
\hline & 80,202 & IA, ID, III & $3,4, \mathrm{~N} 2, \mathrm{BDB}, P$. syzygii & 1 \\
\hline & No restriction & $\mathrm{IB}, \mathrm{IC}$ & $3,4,5$ & 1 \\
\hline \multirow[t]{4}{*}{ McrI, BsiEI } & $35,65,183$ & I & $3,4,5, \mathrm{~N} 2$ & 1 \\
\hline & 202,80 & IIC & 1 & 1 \\
\hline & 65,217 & IIA, IIB, IID, IIIA, IIIB, BDB & $1,2, \mathrm{~N} 2$ & $1,2,3$ \\
\hline & No restriction & IIID, IIIE & P. syzygii & $\ldots$ \\
\hline \multirow[t]{5}{*}{$M n l \mathrm{I}$} & $48,65,68,101$ & IIID, IIIE & P. syzygii & $\ldots$ \\
\hline & $26,65,90,101$ & IIA, IIB, IID & $1,2, \mathrm{~N} 2$ & $1,2,3$ \\
\hline & 101,181 & IIC & 1 & 1 \\
\hline & $20,45,101,116$ & IA, IB, IC & $3,4,5, \mathrm{~N} 2$ & 1 \\
\hline & $65,101,116$ & ID, IIIA, IIIB, IIIC & $3, \mathrm{~N} 2, \mathrm{BDB}$ & $\ldots$ \\
\hline Csp61 & 112,170 & IIC & 1 & 1 \\
\hline RsaI & 111,171 & IIC & 1 & 1 \\
\hline
\end{tabular}


the three groups were further divided into 13 subgroups, according to the 237-nt sequence, which in turn correspond to sequevars or clonal lines as described by Fegan and Prior (6).

Strains belonging to group I were mainly from Asia and Australia, with the exception of the type strain from Guyana (GMI 1000). However, the subgroupings showed no clear distinctions between the strains from Asia and those from Australia. Conspicuously seen is the branching out of the Guyana strain, demonstrating the innate difference of the Asian and Australian strains from South American strains.

Group II was composed of strains that are believed to have originated in America. Unlike group I, group II was divided into four subgroups that had a distinctive pattern in terms of race and biovar classifications. Subgroup IIA corresponds to sequevars 3, 4, and 6 while subgroup IIB corresponds to sequevars 1 and 2 of the new classification scheme by Fegan and Prior (6). A difference in $1 \mathrm{nt}$ separated subgroup IIA (banana strains) from subgroup IIB (potato strains), implying their close relationships. Fegan (7) suggested a common progenitor for Philippine banana and potato strains. Both strains have a narrow host range. The phylogenetic homology among bugtok and moko strains was also evident on the 237-bp sequence despite their differences on disease symptoms. Eden-Green suggested that the two diseases are caused by the same bacterium (5). Furthermore, the close association of the Philippine banana strains from Panama also was evident in the results. Previous studies have suggested a common evolutionary origin of bugtok and moko strains from the Philippines with the Central American moko strains $(15,23,32)$. Another important pattern is that all the isolates belonging to biovar 2 or race 3 were clustered in subgroup IIB regardless of their origin, indicating genetic homogeneity of these kinds of strains. These isolates infect potato worldwide and are believed to have originated in the high Andes region and coevolved with the wild potato. Dissemination may have occurred through movement of infected potato (3) during the Spanish conquest (1). The biovar N2 from South America (R568) also was shown distinguishable to typical biovar 2 strains from potato. The natural hosts of this genetically heterogeneous biovar $\mathrm{N} 2$ are unknown $(9,10)$.

Group III in this study was equivalent to subdivision $2 \mathrm{~b}$ (30) and phylotype IV (6). Japanese N2 strains (MAFF 301558 and MAFF 301559) that belong to group III had been classified previously to subdivision $2 b$ based on the 16S rRNA gene sequence (12). The presence of strains WP20 and $28 \mathrm{MF}$ in group III may have confirmed the occurrence of subdivision $2 b$ isolates in the Philippines. This expanded the scope of these strains that were reported only in Indonesia, Australia, and Japan. Additional characterization of strains WP20 and 28MF showed they utilized trehalose, myo-inositol, and D-ribose, and that they can produce nitrite from nitrate (data not shown). All of these are biovar N2 traits. Sequencing of other genes to confirm this is now ongoing. Our results also suggest that subdivision $2 \mathrm{~b}$ should belong to a separate division containing $R$. solanacearum biovar $\mathrm{N} 2$ strains and closely related strains of $P$. syzygii and

RFLP GROUP



Fig. 3. Restriction fragment length polymorphisms of polymerase chain reaction-amplified 282-bp fragments of different strains of Ralstonia solanacearum. The amplified fragments were digested by NlaIII enzymes and run in $4.5 \% \mathrm{Nu}$ sieve agarose gel. Lanes 1 to 5 show group I profile (116 and $166 \mathrm{bp}$ ), lanes 6 to 10 show the group III profile (54 and $228 \mathrm{bp}$ fragments), and lanes 11 to 15 show the typical group II profile (no restrictions). The size marker used was a 50-bp marker.
$\mathrm{BDB}$, all from Asia. Based on the sequencing results of several studies $(7,12,22,30)$, the $R$. solanacearum strains in this group had a greater intergeneric similarity to BDB and $P$. syzygii than interspecific homology to other strains of $R$. solanacearum. Previous studies reported that the relationship of subdivision $2 \mathrm{~b}$ with the other divisions changes depending on the gene sequenced. Sequence analysis of the polygalacturonase gene showed that members of subdivision $2 b$ were closely related to those of subdivision 2a. Contrastingly, in the sequence analysis of the endoglucanase and 16S-23S rRNA gene intergenic spacer regions, subdivision $2 \mathrm{~b}$ was closer to division 1. Nevertheless, these results confirm the presence of subdivision $2 \mathrm{~b}$.

The close relationship of $R$. solanacearum, $\mathrm{BDB}$, and $P$. syzygii had been reported in several studies $(25,29,30,32)$. In this study, we have shown that BDB is closer to $R$. solanacearum strains belonging to biovar N2 (subgroup IIIB). It also is worth mentioning that, based on the result of the sequencing, we were able to correct some strains of BDB to be $P$. syzygii strains, which were mislabeled, as confirmed by our source. $R$. solanacearum strains in this group belong to sequevars 8 or 9 of the new classification scheme (6).

Lastly, based on the observed restriction sites of the different strains used, it is possible to distinguish $P$. syzygii strains from $R$. solanacearum strains and BDB. Additionally, two subgroups of $P$. syzygii were observed, thus implying that this method also may be used for characterization of $P$. syzygii strains and possibly of BDB strains, too. When $165 R$. solanacearum strains from the Philippines were digested with NlaIII, the strains were separated according to the three groups that corresponded to phylotypes I, II, and IV described by Fegan and Prior (6). Using this method, a reliable diagnosis and classification of $R$. solanacearum can be made within a period of $5 \mathrm{~h}$ or less using boiled cells from bacterial ooze or washed out of plant samples. Strains can be classified according to the new classification scheme proposed by Fegan and Prior (6). This could be helpful when used in combination with the multiplex PCR for distinguishing the phylotypes. This technique also can be used for epidemiological studies in which the true distribution of the strains can be determined. As we have observed, the strains belonging to biovar $\mathrm{N} 2$ were difficult to isolate on the TZCA medium. These strains grew very slowly and can be easily overgrown by strains from biovars 2 and 3 . With this technique, the presence of biovar N2 type (group III) from Japan and the Philippines can be easily detected and consistently differentiated from other isolates.

\section{ACKNOWLEDGMENTS}

Financial assistance for J. Villa was provided by the Ministry of Education, Culture, Sports, 
Science and Technology (Monbukagakusho) Japan. We thank N. Ona, L. Lawas, T. Toda, M. Kubota, and T. Sugiura for their invaluable assistance.

\section{LITERATURE CITED}

1. Buddenhagen, I. W. 1986. Bacterial wilt revisited. Pages 126-43 in: Bacterial Wilt Disease in Asia and the South Pacific. G. J. Persley, ed. ACIAR Proc. No. 13, Canberra, Australia.

2. Chen, W. P., and Kuo, T. T. 1993. A simple and rapid method for the preparation of gramnegative bacterial genomic DNA. Nucleic Acids Res. 21:2260.

3. Ciampi, L., and Sequeira, L. 1980. Multiplication of Pseudomonas solanacearum in resistant potato plants and the establishment of latent infections. Am. Potato J. 57:319-29.

4. Cook, D., Barlow E., and Sequeira, L. 1989. Genetic diversity of $P$. solanacearum: detection of restriction fragment length polymorphisms with DNA probes that specify virulence and hypersensitive response. Mol. Plant-Microbe Interact. 2:113-121.

5. Eden-Green, S. J. 1994. Diversity of Pseudomonas solanacearum and related bacteria in Southeast Asia: new directions for moko disease. Pages 25-34 in: Bacterial Wilt: The Disease and Its Causative Agent, Pseudomonas solanacearum. A. C. Hayward and G. L. Hartman eds. CAB International, Wallingford, UK.

6. Fegan, M., and Prior, P. 2003. How complex is the "Ralstonia solanacearum species complex." In: Bacterial wilt: The Disease and the Ralstonia solanacearum Species Complex. C. Allen, P. Prior, and A. C. Hayward, eds. American Phytopathological Society Press, St. Paul, MN.

7. Fegan, M., Taghavi M., Sly, L. I., and Hayward, A. C. 1998. Phylogeny, diversity and molecular diagnostics of Ralstonia solanacearum. Pages 19-33 in: Bacterial Wilt Disease: Molecular and Ecological Aspects. P. Prior, D. Allen, and J. Elphinstone, eds. Springer-Verlag, Berlin.

8. Genin, S., and Boucher C. 2002. Ralstonia solanacearum: secrets of a major pathogen unveiled by analysis of its genome. Mol. Plant Pathol. 3(3):111-118.

9. Gilling, M., and Fahy, P. 1993. Genetic diversity of Pseudomonas solanacearum biovar 2 and N2 assessed using restriction endoglucanase analysis of total genomic DNA. Plant Pathol. 42:744-753.

10. Gilling, M., and Fahy P. 1994. Genomic fingerprinting: towards unified Pseudomonas solanacearum species complex. Pages 95-112 in: Bacterial Wilt: The Disease and Its Causative Agent, Pseudomonas solanacearum. A.
C. Hayward and G. L. Hartman, eds. CAB International, Wallingford, UK.

11. Hayward, A. C. 1991. Biology and epidemiology of bacterial wilt caused by Pseudomonas solanacearum. Annu. Rev. Phytopathol. 29:65-87.

12. Horita, M., and K. Tsuchiya. 2000. Comparative analysis of Japanese and foreign strains of Ralstonia solanacearum based on $16 \mathrm{~S}$ ribosomal RNA gene sequences. J. Gen. Plant Pathol. 66:132-137.

13. Horita, M., and K. Tsuchiya. 2001. Genetic diversity of Japanese strains of Ralstonia solanacearum. Phytopathology 91:399-407.

14. Hyde, K., McCulloch, B., Akiew, E., Peterson, R., and Diatloff, A.1992. Strategies used to eradicate bacterial wilt of Heliconia (race2) in Cairns, Australia, following introduction of the disease from Hawaii. Australas. Plant Pathol. 21:29-31.

15. Ito, S., Ushijima Y., Fujii T., Tanaka S., Kameya-Iwaki M., Yoshiwara, S., and Kishi, F. 1998. Detection of viable cells Ralstonia solanacearum in soil using a semiselective medium and a PCR technique. J. Phytopathol. 146:379-84.

16. Janse, J. D. 1988. A detection method for Pseudomonas solanacearum in symptomless potato tubers and some data on its sensitivity and specificity. OEPP Bull. 18:343-351.

17. Kelman, A. 1954. The relationship of pathogenicity of Pseudomonas solanacearum to colony appearance on a tetrazolium medium. Phytopathology 44:639-695.

18. Li, X., Dorsh, M., Del Dot T., Sly, L. I., Stackebrandt, E., and Hayward, A. C. 1993. Phylogenetic studies of the rRNA group II pseudomonads based on 16S rRNA gene sequences. J. Appl. Bacteriol. 74:324-329.

19. Lum, K. 1973. Cross inoculation studies of Pseudomonas solanacearum from ginger. MARDI Res. Bull. 1:15-21.

20. Opina, N., Tavner, F., Holloway, G., Wang, J., Li, T., Maghirang, R., Fegan, M., Hayward, A., Krishnapillai, V., Hong, W., Holloway, B., and Timmis, J. 1997. A novel method for development of species and strain-specific DNA probes and PCR primers for identifying Burkholderia solanacearum (formerly Pseudomonas solanacearum). Asia Pac. J. Mol. Biol. Biotechnol. 5(1):19-30.

21. Palleroni, N. J., and Doudorouff, M. 1971. Phenotypic characterization and deoxyribonucleic acid homologies of Pseudomonas solanacearum. J. Bacteriol. 107:690-696.

22. Poussier, S., Trigalet-Demery, D., Vandewalle, P., Goffinet, B., Luisetti, J., and Trigalet, A. 2000. Genetic diversity of Ralstonia solanacearum as assessed by PCR-RFLP of the hrp gene region, AFLP, and 16S rRNA sequence analysis and identification of an African subdivision. Microbiology 146:1679-1692.

23. Raymundo, A., Aves-Ilagan, Y., and Denny, T. P. 1998. Analysis of genetic variation of a population of banana infecting strains in Ralstonia solanacearum. Pages 56-60. in: Bacterial Wilt Disease: Molecular and Ecological Aspects. P. Prior, C. Allen, and J. Elphinstone, eds. Springer-Verlag, Berlin.

24. Rillo, A.1979. Bacterial wilt of banana in the Philippines. FAO Plant Prot. Bull. 27:105108.

25. Roberts, S. J., Eden-Green, S. J., Jones P., and Ambler, D. J. 1990. Pseudomonas syzygii, sp. nov., the cause of Sumatra disease of cloves. Syst. Appl. Microbiol. 13:34-43.

26. Roncal, J., Gutarra, L., and Priou, S. 1999. Rapid differentiation of strains of Ralstonia solanacearum by restriction analysis of PCRamplified fragments. ACIAR Bact. Wilt Newsl. 16:7-10.

27. Salanoubat, M., Genin, S., Artiguenave, F., Gouzy, J., Mangenot, S., Arlat, M., Billault, A., Brottier, P., Camus, J. C., Cattolico, L., Chandler, M., Choisne, N., Claudel-Renard, C., Cunnac, S., Demange, N., Gaspin, C., Lavie, M., Moisan, A., Robert, C., Saurin, W. Schiex, T., Siguier, P., Thebault, P., Whalen, M., Wincker, P., Levy, M., Weissenbach, J., and Boucher, C. A. 2002. Genome sequence of the plant pathogen Ralstonia solanacearum. Nature 415:497-502.

28. Seal, S., Jackson, L., and Daniels, M. 1992. Isolation of a Pseudomonas solanacearum specific DNA probe by subtraction hybridization and construction of a species-specific oligonucleotide primers for sensitive detection by polymerase chain reaction. Appl. Environ. Microbiol. 58:3751-3758.

29. Stead, D. E. 1992. Grouping of plant-pathogenic and some other Pseudomonas spp. by using cellular fatty acid profiles. Int. J. Syst. Bacteriol. 42:281-95.

30. Taghavi, M., Hayward, A. C., Sly, L. I., and Fegan, M. 1996. Analysis of the phylogenetic relationships of strains of Burkholderia solanacearum, Pseudomonas syzygii, and the blood disease bacterium of banana based on 16S rRNA sequences. Int. J. Syst. Bacteriol. 46:10-15.

31. Thompson, J., Higgins, D., and Gibson, T. 1994. CLUSTAL W: improving the sensitivity of Progressive multiple sequence alignment through sequence weighting, position specific gap penalties and weight matrix choice. $\mathrm{Nu}$ cleic Acids Res. 22:4673-4580.

32. Thwaites, R., Mansfield, J., Eden-Green, S., and Seal, S. 1999. RAPD and rep-PCR-based fingerprinting of vascular bacterial pathogens of Musa spp. Plant Pathol. 48:121-128. 